\title{
ВЛИЯНИЕ РИМСКОГО ПРАВА НА СОЗДАНИЕ ФРАНЦУЗСКОГО ГРАЖДАНСКОГО КОДЕКСА И ГЕРМАНСКОГО ГРАЖДАНСКОГО УЛОЖЕНИЯ
}

\section{INSTITUTE FOR REGIONAL ENVIRONMENTAL PROBLEMS "THE INFLUENCE OF ROMAN LAW ON THE CREATION OF THE FRENCH CIVIL CODE AND THE GERMAN CIVIL CODE}

Yu. Potokin

Summary. In the article, the author analyzes the French Civil Code and the German Civil Code, as well as the degree of influence on these laws of Roman law. The exclusivity of the work consists in a detailed historical study of the prerequisites for the creation of legislative acts. Studying their content, the author emphasizes the relevance of the influence of Roman law on the Romano-Germanic system of law. When writing the article, we used formal-theoretical and historical-analytical methods of research. The author argues about the importance of the legislation of France and Germany not only for the whole of Europe, but also for civilization as a whole.

Keywords: French Civil Code, German Civil Code, Roman law, RomanGerman legal family, Napoleon's Code, civil law.
$\mathbf{P}$ ецепция римского права ярче всего наблюдается при формировании германской и французской правовых систем. Будучи базой для становления всей романо-германской правовой семьи, римское право служило источником вдохновения и юридической идеологии, воплощенной в кодексах реформаторской и просветительской эпохи в Европе. Причина такого влияния содержится в самой структуре римского права, в стремлении к логическим последовательностям в нормах права. И первостепенную роль здесь играет кодификация.

Рассмотрим поочередно исторические предпосылки и процессы формирования гражданского законодательства Франции и Германии.

Великие личности творят историю. Это утверждение очень точно характеризует личность Наполеона, о которой написаны многочисленные исторические труды. Этот великий политик и полководец был также отмечен как выдающийся государственный деятель. И прежде всего в этой области его основной заслугой является
Потокин Юрий Николаевич

Аспирант, ГАОУ ВО города Москвы «Московский городской педагогический университет»; ведущий инженер, московский филиал ФГБУ «Уральский государственный научно-исследовательский Институт региональных экологических проблем» yura-potokin@yandex.ru

Аннотация. В статье автор проводит анализ Французского Гражданского Кодекса и Германского Гражданского Уложения, а также степень влияния на эти законы римского права. Исключительность работы состоит в детальном историческом исследовании предпосылок создания законодательных актов. Изучая их содержание, автор подчеркивает актуальность влияния римского права на романо-германскую систему права. При написании статьи использовались формально-теоретический и историко-аналитический методы исследования. Автор приводит доводы о значимости законодательства Франции и Германии не только для всей Европы, но и для цивилизации в целом.

Ключевые слова: Французский Гражданский Кодекс, Германское Гражданское Уложение, римское право, романо-германская правовая семья, Кодекс Наполеона, гражданское право.

разработка и создание Гражданского Кодекса (ФГК), справедливо именуемого Кодексом Наполеона (Code Napoléon). По мере уменьшения мятежного духа французов, с приходом к власти Наполеона, во внутренней политике наметились тенденции к унификации законодательной базы. Французская революция XVIII века способствовала тому, что в дальнейшем во Франции происходит рост авторитета закона и превращение его в основной источник права [1].

Исторически так сложилось, что во Франции до этих событий на северных территориях преобладало обычное право, а на южных - римское право, что объясняется географическим расположением и соседством со странами, в основе которых лежала англо-саксонская система права. Наполеон поставил перед собой задачу устранить эти коллизии в гражданском законодательстве и привести к единообразию и систематизации правовые нормы.

Работа над созданием Гражданского Кодекса началась в 1800 году. В состав комиссии разработчиков во- 
шли знаменитые юристы: Тронше, Порталис, Малльвиль, Биго-Преамне. Наполеон лично принимал участие в заседаниях комиссии, благодаря чему проект был составлен в кратчайшие сроки. Но, вопреки ожиданиям, проект не был поддержан при прохождении в Трибунате, в связи с чем Наполеон принимает решение исключить основных критиков первого Титула «О праве и законах вообще». В результате 21 марта 1804 года был принят Гражданский Кодекс, который действует и сейчас с многочисленными правками. Он послужил основой для разработки аналогичных законов во многих странах: Италии, Бельгии, Швейцарии и других. На Гражданский Процессуальный Кодекс Франции 1806, который установил процедуру для всех инстанций гражданского судопроизводства, также воздействовало римское право [2].

В первую очередь стоит отметить влияние римского права на структуру и идеи, воплощенные в этом Кодексе, а также влияние завоеваний французской революции: равенство граждан перед законом, свобода личности, право собственности, свобода труда (ликвидация цеховой зависимости), свобода убеждений, разделение государства и церкви, отмена феодальных структур и прочее. Кодекс отвечал интересам буржуазии, поддерживал торговлю и промышленность, создавал условия для создания нового экономического общества, воплощал принципы единства прав и свобод.

Структура Кодекса была построена по институционной системе, корни которой восходят к системе изложения римского юриста Гая (Институции). Во вводном Титуле описываются положения об опубликовании, действии и применении норм права, а основная содержательная часть разделена на три книги. В первой книге содержатся статьи о лицах, во второй описаны правила об имуществах и о различных видах собственности, в третьей представлены статьи о способах возникновения права собственности.

Статья 7 постулировала, что осуществление гражданских прав не зависит от качества гражданина, это качество приобретается и сохраняется лишь согласно конституционному закону. Лишение гражданских прав возможно по судебному осуждению или лишению качества француза. Существовало понятие гражданской смерти, при которой осужденный терял собственность на все имущество, которым он владел [3].

Революция привлекла новые классы собственников, на которые опирался Наполеон. Бонапарт создал новый лояльный общественный слой - имперское дворянство, которое не имело привилегий старой аристократии и полностью зависело от милости своего императора. Примечательно то, что ФГК не давал определения праву собственности, ограничиваясь только перечис- лением правомочий. Собственность на имущество приобреталась путем наследования, путем дарения между живыми, по завещанию и в силу обязательств. ФГК ликвидировало феодальную систему наследования, признавая наследование по закону и по завещанию.

Больше всего рецепция римского права ощущается в обязательственных правоотношениях. В статье 1101 дано четкое определение договору: «Договор есть соглашение, посредством которого одно или несколько лиц обязываются перед другим лицом или перед несколькими лицами дать что-либо, сделать что-либо или не делать чего-либо» [3]. Понятие предмета договора совпадает с понятием предмета обязательства. Кодекс уделял большое внимание согласию сторон, поскольку исходя из принципа свободы договора, французское право предоставляет частным лицам возможность устанавливать любые правоотношения, не противоречащие закону.

Обращаясь к историческим предпосылкам создания гражданских кодексов Франции и Германии, необходимо отметить важные события, которые влияли на законодательный процесс. В 1806 году Наполеон принудил австрийского императора Франца І отказаться от титула Германского Императора. В результате Средневековая Священная Римская Империя германской нации перестала существовать. Империю частично заменил Рейнский Союз, который находился под протекторатом Наполеона. Можно проследить и отметить влияние правления Наполеона на все государства Европы. Создание новой Германской Империи относят к 1871 году, что символизирует завершение борьбы за объединение всех немецких земель (без Австрии). Империя возникла в условиях победной войны против Франции, в результате чего удалось создать единое Германское государство и укрепить национальное самосознание немцев. В связи с этими событиями возникла острая необходимость в создании своего национального законодательства, так как в Германии дольше, чем в других странах существовала правовая раздробленность.

Германское Гражданское Уложение (Bürgerliches Gesetzbuch - ГГУ) было принято в 1896 году. Первая комиссия из 11 юристов взялась за дело в 1874 и работала на протяжении 13 лет. В 1887 году она представила первый проект, состоявший из 5 толстых томов [4]. Этот проект подвергся критике, была назначена новая комиссия. А 18 августа 1896 года был утвержден второй проект, вступивший в силу только с 1900 года.

ГГУ приобрело мировую известность, общая часть которого была заимствована в разных объемах бразильскими, португальскими, греческими, нидерландскими, японскими, китайскими и российскими законодателями 
[5]. ГГУ в значительной степени базируется на римском праве, но также содержит нормы германского законодательства. ГГУ построено по пандектной системе. Пандектное право - римское частное право, действовавшее в измененном виде в Германии в XVI-XIX веках. B соответствии с пандектной системой единые для всех институтов нормы находятся в общей части. Кроме этого ГГУ содержит еще 4 книги. Первая книга - это как раз общая часть, вторая содержит нормы обязательственных правоотношений, третья посвящена вещному праву, четвертая - семейному, пятая - наследственному.

Буржуазия Германии также провозгласила свободу и равенство главными ценностями государства. Сохраняются идеалы распоряжения частной собственностью. Статья 903 гласит: «Собственник вещи властен, настолько тому не препятствует закон или права третьих лиц, распоряжаться вещью по своему усмотрению и устранять других от всякого на нее воздействия» [6]. Германский законодатель предъявляет дополнительные требования к передаче недвижимого имущества: для отчуждения недвижимости требуется публичный акт - запись в По- земельной Книге. И вслед за римским законодателем, Уложение исключает возможность возврата движимой вещи добросовестным приобретателем, если вещь вышла из обладания собственника по его воле [7].

ГГУ имеет отличительную особенность, выраженную в сочетании патриархальных традиций с либеральными ценностями.

Следуя бесценному опыту и урокам истории, цивилизация перенимает позитивную практику государственного и общественного управления, отбрасывая нежизнеспособные элементы. Исследованные выше законы позволяют сделать вывод о значимости влияния римского права на гражданское законодательство Германии и Франции. Что выражается в способах возникновения права собственности, равенстве граждан перед законом, наследственных правоотношениях, выражении свободы воли при заключении договора. И, как следствие, отмечается значимость германского и французского гражданского права на становление всей романо-германской правовой семьи.

\section{ЛИТЕРАТУРА}

1. Тивоненко Е.В. Гражданский кодекс Наполеона: его создание и значение // В сборнике: Событие и текст: встречи и размышления в библиотеке. сборник научных статей по материалам Республиканского научно-просветительского лектория. Уфа, 2017. С. 150-154.

2. Жалламион К. Французская традиция арбитража // Вестник Российского университета дружбы народов. Серия: Юридические науки. 2018. Т. 22. № 2. C. 289-306.

3. Гражданский кодекс (Кодекс Наполеона) 1804 г. // [Электронный ресурс] режим доступа: URL https://pandia.ru/text/77/231/34260.php (дата 0бращения: 26.03.2021).

4. Вахрушева С.Н., Перевозникова П.А. Германское гражданское уложение - результат правотворчества // Научный альманах. 2017. № 3-1 (29). С. 300303.

5. Виноградова 0.П. Германское гражданское уложение 1896 г. как образец буржуазной кодификации права // Вестник Уральского юридического института МВД России. 2015. № 4. С. 77-83.

6. Германское Гражданское Уложение 18 августа 1896 г. (споследующими изменениями) // [Электронный ресурс] режим доступа: URL https://pnu.edu.ru/ru/ faculties/full_time/uf/iogip/study/studentsbooks/histsources2/igpzio63/ (дата обращения: 26.03.2021).

7. Шеметова Н.Ю. Европейское законодательство (средневековье, XVII век — начало XX века) об особенностях оборота недвижимого имущества // Вестник Калининградского филиала Санкт-Петербургского университета МВД России. 2015. № 2 (40). С. 88-90. 